\title{
Study on the Efficacy of Pondguard in Improving Clinical Performance of White Leg Shrimp (Penaeus Vannamei) in an AHPND Bacterial Challenge Model
}

\author{
Haig Yousef Babikian ${ }^{1 *}$, Rajeev Kumar Jha', Dang Thi Hoang Oanh ${ }^{2}$ and Truong Quoc Phu ${ }^{2}$ \\ ${ }^{1}$ PT Central Proteina Prima, Indonesia \\ ${ }^{2}$ Department of Aquaculture and Fisheries, Cantho University, Vietnam
}

*Corresponding author: Haig Yousef Babikian, PT Central Proteina Prima, Indonesia.

To Cite This Article: Haig Yousef Babikian. Study on the Efficacy of Pondguard in Improving Clinical Performance of White Leg Shrimp (Penaeus Vannamei) in an AHPND Bacterial Challenge Model.Am JBiomed Sci \& Res. 2019- 5(3).AJBSR.MS.ID.000914.DOI:10.34297/AJBSR.2019.05.000914.

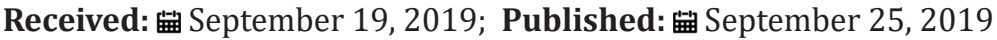

\begin{abstract}
A bioassay trial was conducted to determine the efficacy of developed product, Pondguard as an anti-Acute Hepatopancreatic Necrosis Disease (AHPND) candidate. The Pondguard (Registration no. D 16060285-HBC) is consisting of natural oils, like, lavender oil, Eucalyptus oil and Pine oil. It maintains the immunity level of shrimp, which helps to protect shrimp from infectious diseases. Two doses of Pondguard i.e. $40 \mathrm{ppm}$ and $80 \mathrm{ppm}$ were selected for the trial. The treatment groups tanks were applied Pondguard whereas no application in control tanks throughout the experiment. The shrimp of both treatment and control were challenged by immersion method. The cumulative mortality reached up to $56.7 \%$ in positive control whereas $23.3 \%$ in 80 ppm pondguard group and $13.3 \%$ in 40 ppm pondguard group at dpi 8 whereas no mortality recorded in negative control. The Relative Percent Survival of $80 \mathrm{ppm}$ group was $64.7 \%$ and of $40 \mathrm{ppm}$ group was $76.5 \%$. The trial results show that the developed Pondguard has significant effect against AHPND-Vibrio parahaemolyticus in a controlled condition.
\end{abstract}

Keywords: AHPND; Vibrio parahemolyticus; Essential Oil Blend; Pondguard

\section{Introduction}

The Acute Hepatopancreatic Necrosis Disease (AHPND) or Early Mortaliy Syndrome (EMS) have been reported in several shrimp producing countries, like, Vietnam, Malaysia, Thailand, Mexico and in Philipines [1-5]. There is significant impact on the world shrimp production $[1,6]$, were successfully able to identify and isolate the causative agent Vibrio parahaemolyticus of AHPND. The unique symptoms and characteristics of this disease include severe atrophy of the shrimp hepatopancreas (HP) consisting of massive sloughing of HP epithelial cells [1]. The external symptoms in infected shrimp like, empty stomach, bluish body color and shrunken hepatopancreas, could be observed in the outbreak ponds. AHPND could transmit experimentally by horizontal transmission, co-habitation, immersion and by reverse gavage (Personal observation).

The AHPND appear in the culture ponds from 8-45 days of stocking. The shrimp cultured in earthen bottom ponds were reported more susceptible to AHPND as compared to the HDPE-lined ponds. The proposed trial was designed with the objective to conduct a laboratory scale trial by applying the developed anti-AHPND product i.e. Pondguard to determine its efficacy against the AHPND causative agent. The pre-determined doses, $40 \mathrm{ppm}$ and $80 \mathrm{ppm}$ were used to conduct the trial. The bioassay trial was conducted by the researchers of Department of Aquaculture and Fisheries, Cantho University, Cantho, Vietnam.

\section{Materials and Methods}

\section{Experimental shrimp}

White leg shrimp larvae (PL10) were spawned and nursed to 0.5 to $1 \mathrm{~g} /$ individual (size most affected by AHPND) in recirculation system at shrimp hatchery and nursery of College of Aquaculture and Fisheries, Cantho University, Vietnam. Prior to being distributed to experimental aquarium, three shrimp samples were screened by PCR for Infectious Hematopoetic and Hypodermal Necrosis Virus, White Spot Syndrome Virus, Monodon Baculorvirus. Taura syndrome Virus. Vibrio parahaemolyticus causing AHPND and Enterocytozoon hepatopeanaei to ensure shrimp were free from those specific pathogens. Experimental shrimp were in good health prior to being distributed to experimental aquaria. Moulting shrimp were removed prior to start of feeding and prior to challenge. Prior to start of Pondguard application and prior to challenge, weight and length of 30 shrimp were measured. Prior to start of trial, the 
average weight was $0.5 \mathrm{~g}$ and average length was $4.33 \mathrm{~cm}$. Prior to challenge average weight was $1.4 \mathrm{~g}$.

\section{Experimental system}

Glass aquaria (30 L in volume) were used to set up the trial. Each aquarium contained $25 \mathrm{~L}$ of seawater (15\%) with continuous aeration system and temperature was maintained around $26-30^{\circ} \mathrm{C}$. Experimental shrimp were stocked with the density of 40 individuals/aquaria (before challenge) and 15-20 individuals/aquaria (on challenge). The treatment and control groups were reared in 2 different rooms. The distance between two rooms was about 30 meters.

\section{Feeding}

The CP Prima, Indonesia for the trial, provided feed. The proximate composition of both feeds was the same. The feeding rate was $7 \%$ of MBW and the feeding frequency was 4 times/day (at 7AM, $11 \mathrm{AM}, 1 \mathrm{PM}$ and $7 \mathrm{PM}$ ) throughout the trial period.

\section{Pondguard}

The CP Prima, Indonesia for the trial, provided Pondguard. The Pondguard is consist of Natural oils, like, lavender oil, Eucalyptus oil and Pine oil. It maintains the immunity level of shrimp, which helps to protect shrimp from infectious diseases. The Pondguard is registered under Ministry of Aquaculture, Indonesia with Registration no. D 16060285-HBC. The different concentration of Pondguard (40ppm, 80ppm) was applied to obtain the best dose to act against AHPND. The dose of Pondguard for the current trial was determined on the basis of previous study trial outcome. The de- termined dose of pondguard was started applying two days prior to challenge. It was applied on daily basis throughout the trial period.

\section{Bacterial challenge}

The bacterial strain used in this study was designated V36. This strain was originally isolated from shrimp diagnosed with AHPND histopathology (Strain was isolated from diseased shrimp collected in Soc Trang province in September 2016). Strain was stored at $-80^{\circ} \mathrm{C}$ in TSB supplementing with $1.5 \% \mathrm{NaCl}$ and $25 \%$ glycerol. The bacteria were identified as $V$. parahaemolyticus by green colonies on TCBS. Conventional API 20E biochemical tests and PCR with LTH primers [7]. Additionally, the isolate was positive on PCR with AP3 primers [8].

Bacterial culture were grown $24 \mathrm{~h}$ in TSB supplementing with $1.5 \% \mathrm{NaCl}$ at $28^{\circ} \mathrm{C}$. Based on the standard curve determined for the strain. The OD corresponding to $10^{8}$ cells ml- 1 was diluted in seawater. Immersion method of challenge was applied in the experiment [9]. Shrimp were immersed for 15 minutes in this bacterial culture with continuous aeration and then both bacterial solution and shrimp were transferred to aquaria containing seawater reducing the bacterial concentration to $10^{6}$ cells $\mathrm{ml}^{-1}$. No water was exchanged for 48 hours after the challenge. Then $30 \%$ of water was renewed every 2 day.

\section{Experimental design}

Set up in 4 groups with 25L water. Challenge with V36 strain and added test products as detail in Table 1. Clinical signs observation and recording were followed up for 7 days post challenge.

\begin{tabular}{|c|c|c|c|c|c|c|}
\hline \multicolumn{6}{|c|}{ Table 1: Experimental set up to test the response to AHPND of juvenile shrimp Penaeus vannamei treated with CPP product Pondguard. } \\
\hline No & Lab & Group & Description & Pondguard & Replicate tanks & Number of shrimp/tank \\
\hline 1 & A & Positive Control & Regular Feed + EMS & - & 3 & 20 pcs \\
\hline 2 & B & Treatment Group 1 & Regular Feed + 40 ppm BAV Liquid+EMS & 4.8 ppm & 3 & 20 pcs \\
\hline 3 & B & Treatment Group 2 & Regular Feed + 80 ppm BAV Liquid+ EMS & $9.6 \mathrm{ppm}$ & 3 & $20 \mathrm{pcs}$ \\
\hline 4 & B & $\begin{array}{c}\text { Negative Control+ } \\
\text { Negative TSB+ }\end{array}$ & Regular Feed + TSB; No EMS & - & 1 & 20 pcs \\
\hline
\end{tabular}

Cross-contamination of bacteria between tanks was avoided by covering the tanks and assigning separate equipment to tanks. Monitor water quality. Siphoning and water exchange 30\% every 2 day. Clinical follow-up 2 times per day.

\section{Data collection}

1. Cumulative mortality

2. Severity and time of onset of clinical signs

3. PCR (IHHNV, WSSV, MBV, TSV, Vibrio parahaemolyticus causing AHPND and EHP): Before stocking to aquarium.

4. PCR (Vibrio parahaemolyticus causing AHPND): 2 days (48hrs) after challenge.

5. Total Vibrio Count on TCBS: before challenge, 3-hour post challenge, 6hour post challenge and 24 hour post challenge.

6. Relative Percent Survival

\section{Results}

\section{Result Pondguard application}

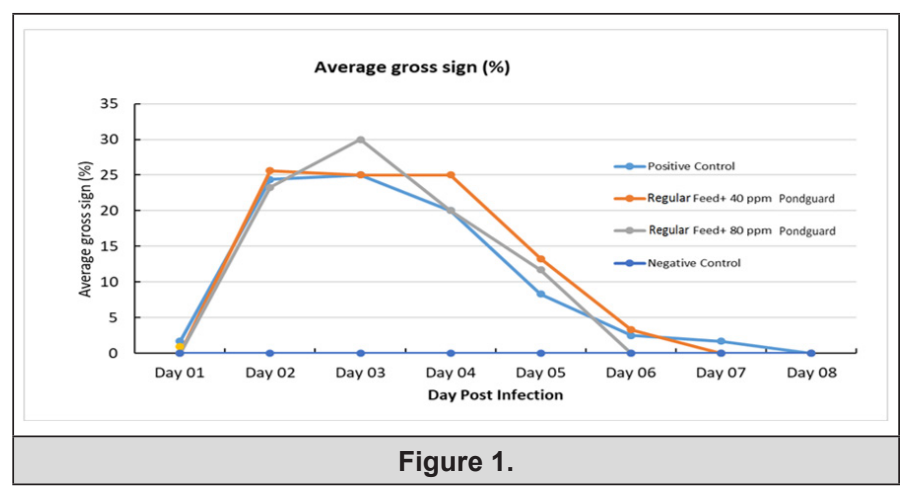

Clinical signs: Challenged shrimp displayed clinical signs (such as anorexia, lethargic swimming, pale coloration of the body and hepatopancreas) starting after 9 hours post challenge. Typical 
gross signs of AHPND (gut with dis-continuous content or empty gut and HP became pale color) were clearly seen after 21 hours post challenge (Figure 1).

The gross sign started recovering after day 4-5 of challenge in the groups. Summary of gross sign at 7 days post challenge are com pared and presented in Table 2 .

\section{Cumulative mortality}

Mortalities were started at $9 \mathrm{hrs}$ of post challenge and seen clearly at $21-24 \mathrm{hrs}$ of post challenge. The average cumulative mortality are presented in Figure 2.

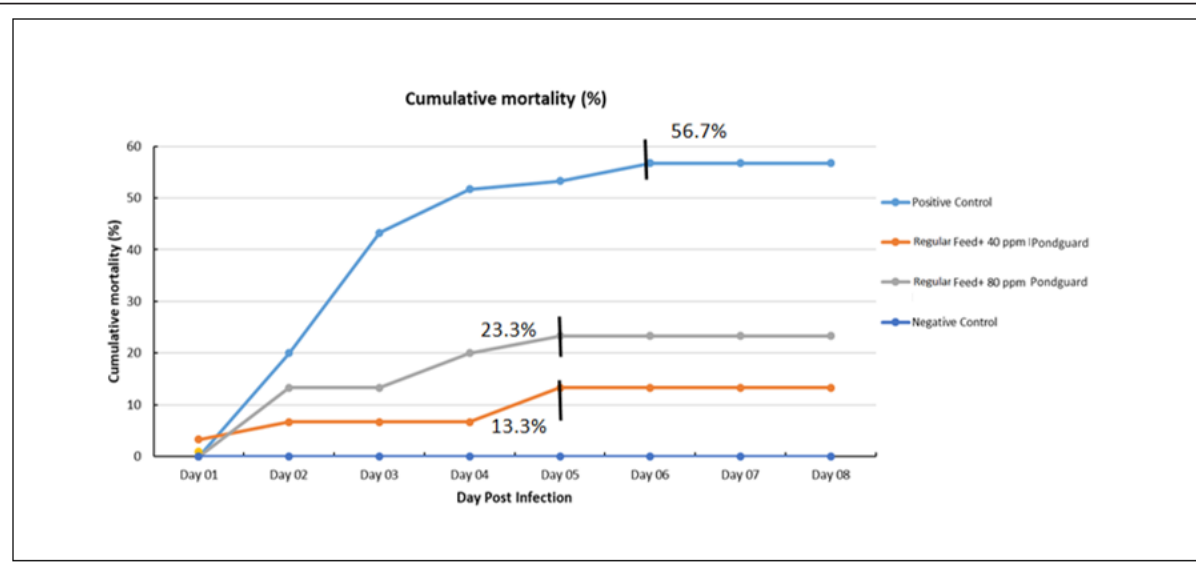

Figure 2. Cumulative mortality of shrimp fed with regular Feed+Pondguard.

Summary of cumulative mortality at 7 days after challenge from different treatment groups are compared and presented in (Table 2). The lowest cumulative mortality was $13.3 \%$ in Treatment Group 1 (regular Feed + 40 ppm Pondguard+EMS).

\section{RPS (Relative Percent Survival) on the basis of Cumula- tive Mortality (CM)}

RPS (Relative Percent Survival) on the basis of Cumulative Mortality $(\mathrm{CM})$

\begin{tabular}{|c|c|c|}
\hline \multicolumn{2}{|c|}{ Table 2. } & GPI 7 \\
\hline No & CM Positive Control & $56.70 \%$ \\
\hline 1 & CM (Regular Feed+40 ppm Pondguard+EMS) & $13.30 \%$ \\
\hline 2 & CM (Regular Feed+80 ppm Pondguard+EMS) & $23.30 \%$ \\
\hline 3 & RPS (Regular Feed+ 40 ppm Pondguard+EMS) & $76.50 \%$ \\
\hline 5 & RPS (Regular Feed+ 80 ppm Pondguard+EMS) & $58.80 \%$ \\
\hline
\end{tabular}

Formula $=1-(\%$ mortality in Treatment Group $/ \%$ mortality in $\quad$ TCBS plate counting

Positive Control) x 100

The best RPS value recorded was $76.5 \%$ of group 4 (Regular feed +40 ppm Pondguard +EMS) which was followed by group 2 (regular Feed + 80 ppm Pondguard +EMS) i.e. 64.7\%.
Comparison of total Vibrio count from water samples collected from different treatments of experiment is presented in Figure 3. Sample was taken before challenge, 3-hour post challenge, 6-hour post challenge, and 24-hour post challenge.

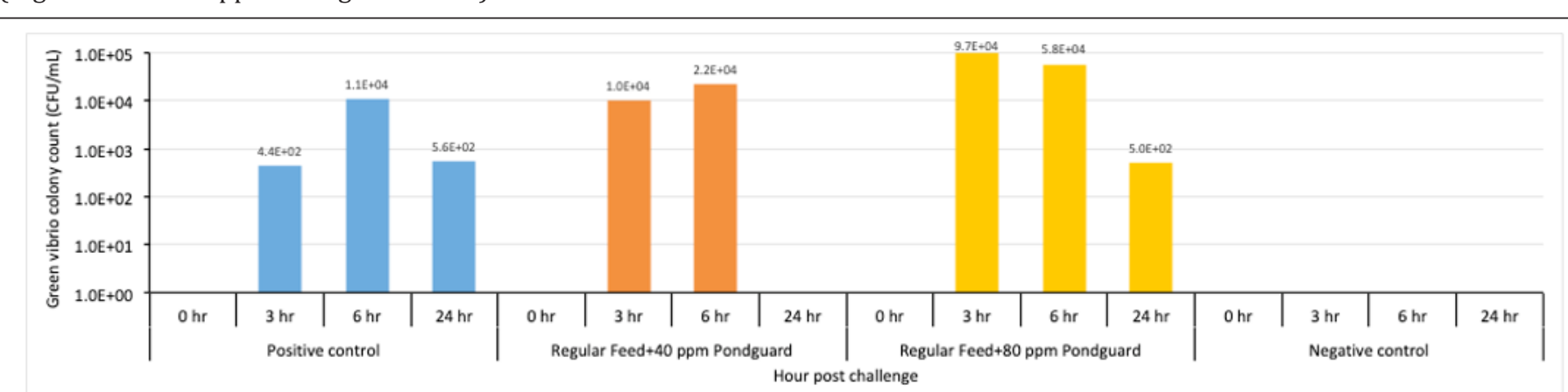

Figure 3. Green colony of bacteria in water sample trial tanks (Regular Feed + Pondguard).

All the challenged tanks showed presence of vibrio bacteria in the water after challenge. The pick count recorded at 6 hours and then reduction of vibrio at $24 \mathrm{hr}$ interval. The water samples were collected from 2 tanks each of Pondguard tanks, all three tanks of Positive control and 1 tank of negative control groups (Table-3). 
Table 3: TCBS plate counting from water samples of trial tanks (Regular Feed+Pondguard).

\begin{tabular}{|c|c|c|c|c|c|c|}
\hline \multirow{2}{*}{ Period } & \multirow{2}{*}{ Group } & \multirow{2}{*}{ Tank } & \multicolumn{3}{|c|}{ Vibrio count (CFU/ml) } & \multirow{2}{*}{$\begin{array}{l}\text { Total Vibrio count } \\
\text { (CFU/ml) }\end{array}$} \\
\hline & & & Green & Yellow & Black & \\
\hline \multirow{11}{*}{ Before challenge } & \multirow{4}{*}{ Positive Control (Regular Feed + EMS) } & $\mathrm{C} 1$ & $0.0 . \mathrm{E}+00$ & 6.7.E+01 & $0.0 . E+00$ & 6.7.E+01 \\
\hline & & $\mathrm{C} 2$ & $0.0 . \mathrm{E}+00$ & 6.7.E+01 & $0.0 . \mathrm{E}+00$ & 6.7.E+01 \\
\hline & & $\mathrm{C} 3$ & $0.0 . \mathrm{E}+00$ & 6.7.E+01 & $0.0 . \mathrm{E}+00$ & 6.7.E+01 \\
\hline & & AVG & $0.0 . \mathrm{E}+00$ & 6.7.E+01 & $0.0 . E+00$ & 6.7.E+01 \\
\hline & \multirow{3}{*}{ Regular Feed+40 ppm Pondguard+ EMS } & $\mathrm{T} 10$ & $0.0 . \mathrm{E}+00$ & 3.3.E+01 & $0.0 . E+00$ & 3.3.E+01 \\
\hline & & $\mathrm{T} 11$ & $0.0 . \mathrm{E}+00$ & 6.7.E+01 & $0.0 . E+00$ & 6.7.E+01 \\
\hline & & AVG & $0.0 . \mathrm{E}+00$ & $5.0 . \mathrm{E}+01$ & $0.0 . E+00$ & $5.0 . \mathrm{E}+01$ \\
\hline & \multirow{3}{*}{ Regular Feed+80 ppm Pondguard+ EMS } & $\mathrm{T} 12$ & $0.0 . \mathrm{E}+00$ & 3.3.E+01 & $0.0 . E+00$ & 3.3.E+01 \\
\hline & & $\mathrm{T} 13$ & $0.0 . \mathrm{E}+00$ & 3.3.E+01 & $0.0 . E+00$ & 3.3.E+01 \\
\hline & & AVG & $0.0 . \mathrm{E}+00$ & 3.3.E+01 & $0.0 . E+00$ & 3.3.E+01 \\
\hline & Negative control (RegularFeed + No EMS) & TN1 & $0.0 . \mathrm{E}+00$ & 3.3.E+01 & $0.0 . E+00$ & 3.3.E+01 \\
\hline \multirow{11}{*}{$\begin{array}{l}\text { 3-hour post } \\
\text { challenge }\end{array}$} & \multirow{4}{*}{ Positive Control (Regular Feed + EMS) } & $\mathrm{C} 1$ & $0.0 . \mathrm{E}+00$ & $0.0 . \mathrm{E}+00$ & $0.0 . \mathrm{E}+00$ & $0.0 . \mathrm{E}+00$ \\
\hline & & $\mathrm{C} 2$ & 3.3.E+02 & $0.0 . E+00$ & $0.0 . E+00$ & 3.3. $E+02$ \\
\hline & & $\mathrm{C} 3$ & 1.0.E+03 & 6.7.E+02 & $0.0 . E+00$ & 1.7. $E+03$ \\
\hline & & AVG & 4.4.E+02 & $2.2 . E+02$ & $0.0 . E+00$ & 6.7.E+02 \\
\hline & \multirow{3}{*}{ Regular Feed+40 ppm Pondguard+ EMS } & $\mathrm{T} 10$ & 1.0.E+04 & $0.0 . \mathrm{E}+00$ & $0.0 . E+00$ & 1.0.E+04 \\
\hline & & T11 & 1.0.E+04 & 6.7.E+04 & $0.0 . \mathrm{E}+00$ & 7.7.E+04 \\
\hline & & AVG & 1.0.E+04 & 3.3.E+04 & $0.0 . E+00$ & 4.3.E+04 \\
\hline & \multirow{3}{*}{ Regular Feed+80 ppm Pondguard+ EMS } & $\mathrm{T} 12$ & 9.7.E+04 & $6.7 . E+03$ & $0.0 . E+00$ & 1.0.E+05 \\
\hline & & $\mathrm{T} 13$ & 9.7.E+04 & $0.0 . \mathrm{E}+00$ & $0.0 . E+00$ & 9.7.E+04 \\
\hline & & AVG & 9.7.E+04 & 3.3.E+03 & $0.0 . E+00$ & 1.0.E+05 \\
\hline & Negative control (Regular Feed + No EMS) & TN1 & $0.00 \mathrm{E}+00$ & $0.00 \mathrm{E}+00$ & $0.00 \mathrm{E}+00$ & $0.00 \mathrm{E}+00$ \\
\hline \multirow{11}{*}{$\begin{array}{l}\text { 6-hour post } \\
\text { challenge }\end{array}$} & \multirow{4}{*}{ Positive Control (Regular Feed + EMS) } & $\mathrm{C} 1$ & $0.0 . \mathrm{E}+00$ & 6.7.E+04 & $0.0 . E+00$ & 6.7.E+04 \\
\hline & & $\mathrm{C} 2$ & 3.3.E+04 & 1.0.E+05 & $0.0 . E+00$ & 1.3.E+05 \\
\hline & & C3 & $0.0 . \mathrm{E}+00$ & 3.3.E+04 & $0.0 . \mathrm{E}+00$ & 3.3.E+04 \\
\hline & & AVG & 1.1.E+04 & 6.7.E+04 & $0.0 . E+00$ & 7.8.E+04 \\
\hline & \multirow{3}{*}{ Regular Feed+40 ppm Pondguard+ EMS } & T10 & 3.3.E+04 & 3.3.E+03 & $0.0 . E+00$ & 3.7.E+04 \\
\hline & & $\mathrm{T} 11$ & 1.0.E+04 & $3.3 . E+03$ & $0.0 . E+00$ & 1.3.E+04 \\
\hline & & AVG & $2.2 . E+04$ & $3.3 . E+03$ & $0.0 . E+00$ & $2.5 . E+04$ \\
\hline & \multirow{3}{*}{ Regular Feed+80 ppm Pondguard+ EMS } & T12 & 3.3.E+04 & $0.0 . \mathrm{E}+00$ & $0.0 . \mathrm{E}+00$ & 3.3.E+04 \\
\hline & & $\mathrm{T} 13$ & 8.3.E+04 & 6.7.E+03 & $0.0 . \mathrm{E}+00$ & $9.0 . \mathrm{E}+04$ \\
\hline & & AVG & 5.8.E+04 & 3.3.E+03 & $0.0 . E+00$ & $6.2 . \mathrm{E}+04$ \\
\hline & Negative control (Regular Feed + No EMS) & TN1 & $0.00 \mathrm{E}+00$ & $0.00 \mathrm{E}+00$ & $0.00 \mathrm{E}+00$ & $1.00 \mathrm{E}+03$ \\
\hline \multirow{11}{*}{$\begin{array}{l}\text { 24-hour post } \\
\text { challenge }\end{array}$} & \multirow{4}{*}{ Positive Control (Regular Feed + EMS) } & $\mathrm{C} 1$ & $6.7 . \mathrm{E}+02$ & 1.7.E+03 & $0.0 . E+00$ & 2.3.E+03 \\
\hline & & $\mathrm{C} 2$ & $0.0 . \mathrm{E}+00$ & $0.0 . \mathrm{E}+00$ & $0.0 . \mathrm{E}+00$ & $0.0 . E+00$ \\
\hline & & $\mathrm{C} 3$ & $1.0 . \mathrm{E}+03$ & 5.3.E+03 & $0.0 . E+00$ & 6.3.E+03 \\
\hline & & AVG & 5.6.E+02 & 2.3.E+03 & $0.0 . E+00$ & 2.9.E+03 \\
\hline & \multirow{3}{*}{ Regular Feed+40 ppm Pondguard+ EMS } & $\mathrm{T} 10$ & $0.0 . \mathrm{E}+00$ & $0.0 . E+00$ & $0.0 . E+00$ & $0.0 . E+00$ \\
\hline & & $\mathrm{T} 11$ & $0.0 . \mathrm{E}+00$ & $0.0 . \mathrm{E}+00$ & $0.0 . E+00$ & $0.0 . \mathrm{E}+00$ \\
\hline & & AVG & $0.0 . \mathrm{E}+00$ & $0.0 . \mathrm{E}+00$ & $0.0 . E+00$ & $0.0 . E+00$ \\
\hline & \multirow{3}{*}{ Regular Feed+80 ppm Pondguard+ EMS } & $\mathrm{T} 12$ & $0.0 . \mathrm{E}+00$ & $0.0 . \mathrm{E}+00$ & $0.0 . E+00$ & $0.0 . E+00$ \\
\hline & & $\mathrm{T} 13$ & 1.0.E+03 & 3.0.E+00 & $0.0 . \mathrm{E}+00$ & 1.0.E+03 \\
\hline & & AVG & $5.0 . \mathrm{E}+02$ & $1.5 . \mathrm{E}+00$ & $0.0 . \mathrm{E}+00$ & $5.0 . \mathrm{E}+02$ \\
\hline & Negative control (Regular Feed + No EMS) & TN1 & $0.0 . \mathrm{E}+00$ & $0.0 . \mathrm{E}+00$ & $0.0 . E+00$ & $0.0 . E+00$ \\
\hline
\end{tabular}




\section{PCR analysis}

Before stocking to the aquarium, three shrimp samples were screened by PCR for Infectious Hematopoetic and Hypodermal Necrosis Virus, White Spot Syndrome Virus, Monodon Baculorvirus. Taura syndrome Virus. Vibrio parahaemolyticus causing AHPND and Enterocytozoon hepatopeanaei to ensure shrimp were free from those specific pathogens. Sample of hepatopancreas and stomach were collected from moribund shrimp for PCR (Vibrio parahaemolyticus causing AHPND) was taken on day 2 after challenge (48hour after challenge). All the treatment groups samples detected positive to EMS. The negative control (Not challenged) samples detecetd negative to EMS. Strain 13-028/A3 was determined to cause this disease through laboratory bioassays [6] (Figure 4).

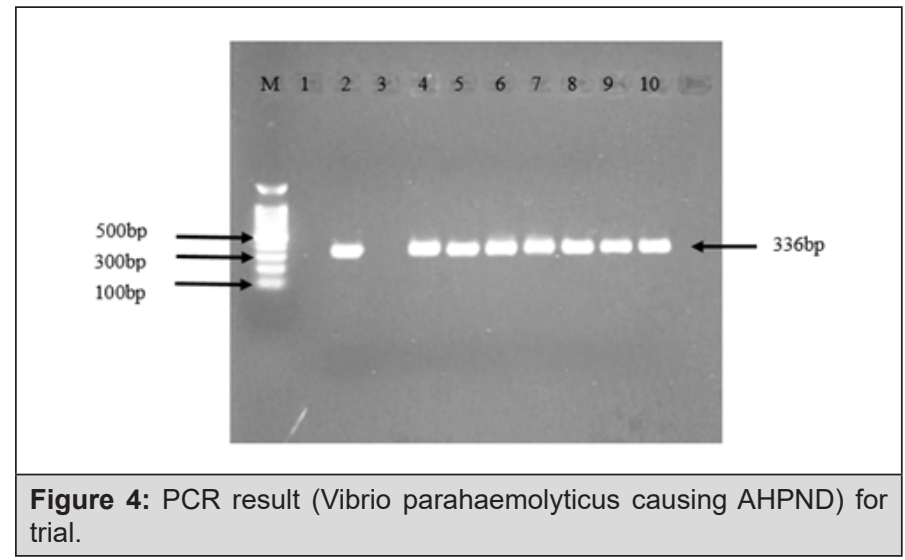

1. Lane M: Marker $100 \mathrm{bp}$

2. Lane 1: PCR Negative control

3. Lane 2: PCR Positive control

4. Lane 3: Negative control

5. Lane 4: Positive control

6. Lane 5: Regular Feed+EMS

7. Lane 6: Regular Feed+40 ppm Pondguard+EMS

8. Lane 7: Regular Feed+40 ppm Pondguard+EMS

9. Lane 8: Regular Feed+80 ppm Pondguard+EMS

10. Lane 9: Regular Feed+80 ppm Pondguard+EMS

11. Lane 10: No BAV Feed+80 ppm BAV Liquid+EMS

\section{Conclusions}

The dose 40 ppm has shown better Relative percent survival value. There is $100 \%$ reduction in green Vibrio within 24 hours of challenge in the presence of Pondguard. The developed natural oil formulated product, Pondguard, has shown potential to be claimed as anti-AHPND/EMS product on the basis of lab scale trial.

\section{Discussion}

The obtained laboratory results states that in a controlled environment Pondguard containing natural oil extracts provide pre- vention against AHPND. The treatment shrimp that challenged with AHPND/EMS V. parahemolyticus showed lower mortality rate as compared to positive control group. Furthermore, the obtained results and analysis gave a clear indication that we have identified a solution to combating EMS outbreaks in a controlled environment. The AHPND gross-sign appearance in the challenged shrimp was similar and as described by [6,10-12]. The rate of mortality in the challenged group was similar to the field reports i.e. heavy mortality for 3 to 5 days with significant drop in feed intake. The bioassay challenge trial conducted by [6] received the similar rate of mortality as recorded in the positive control of the current trial. The herbal origin products have proven to be anti-bacterial and anti-viral properties [13-16]. The next step would be conducting a field trial in the culture ponds [17-21].

\section{Acknowledgments}

The authors are thankful to Department of Aquaculture and Fisheries, Cantho University, Cantho, Vietnam for granting permission to conduct the trial. The authors are also thankful to PT. Central Proteina Prima Tbk. for providing necessary fundings and assistance to conduct the trials in Vietnam.

\section{References}

1. Lightner DV, R Redman, C Pentoja, B Noble, L Tran (2012) Early mortality syndrome affects shrimp in Asia. Global Aquaculture Advocate 15-20.

2. Mooney A (2012) An emerging shrimp disease in Vietnam, microsporidiosis or liver disease?

3. Flegal TW (2012) Historic emergence, impact and current status of of shrimp pathogens in Asia J Invertebr Pathol 110(2):166-173.

4. Nunan L, D Lightner, C Pantoja, S Gomez Jinenez (2014) Detection of acute hepatopancreatic necrosis disease (AHPND) in Mexico. Dis Aquat Organ 111(1): 81-86.

5. Leaño EM, CV Mohan (2012) Early Mortality Syndrome threatens Asia's shrimp farms. Global Aquaculture advocate 38-39.

6. Tran L, L Nunan, RM Redman, LL Mohney, CR Pantoja, et al. (2013) Determination of the infectious nature of the agent of acute hepatopancreatic necrosis syndrome affecting penaeid shrimp. Dis Aquat Org 105(1): 45-55.

7. Kaysner C, DePaola A (2004) Vibrio. In: BAM Council (eds) Bacteriological analytical manual online. US Food and Drug Administration.

8. Sirikharin R, S Taengchaiyaphum, K Sritunyalucksana, S Thitamadee, TW Flegel (2014) A new and improved PCR method for detection of AHPND bacteria.

9. Saulnier D, P Haffner, C Goarant, P Levy, D Ansquer (2000) Experimental infection models for shrimp vibriosis studies: a review. Aquaculture 191:133-144.

10. NACA (2012) Disease card: Diseases of crustaceans - Acute hepatopancreatic necrosis syndrome.

11. OIE (2013) Technical Disease Cards : Acute Hepatopancreatic necrosis syndrome.

12. Sivasankar P, Santhiya A, Kanaga V (2015) A review on plants and herbal extracts against viral disease in aquaculture. Journal of Medicinal Plants Studies 3(2): 75-79.

13. Balasubramanian G, Sudhakaran R, Syed Musthaq S, Sarathi M, Hameed ASS (2006) studies on the inactivation of white spot syndrome virus of shrimp by physichal and chemical treatments and seaweed extracts tested in marine and freshwater animal models. J Fish Dis 29(9): 569-572. 
14. Balasubramanian G, Sarathi M, Venkatesan C, Thomas J, Hameed ASS (2008) Oral administration of antiviral plant extract of Cynodon dactylon on a large scale production against white spot syndrome virus (WSSV) in Penaeus monodon. Aquaculture 279(1-5):2-5.

15. Harikrishnan R, Balasundaram C, Heo MS (2011) Impact of plant products on innate and adaptive immune system of cultured finfish and shellfish. Aquaculture 317(1-4): 1-15.

16. Mohamadi M, Zamini AA, Vahabzadeh H (2013) Evaluation of Antibacterial Properties of Eucalyptus spp and Plelargonium roseum Extracts in Common carp, Cyprinus carpio and Their Effects on Blood Indices. Middle East Journal of Scientific Research 15(5): 723-731.

17. FAO. 2013. Report of the FAO/MARD Technical Workshop on Early Mortality Syndrome (EMS) or Acute Hepatopancreatic Necrosis Syndrome (AHPNS) of Cultured Shrimp (under TCP/VIE/3304). FAO Fisheries and Aquaculture Report No. 1053. Rome. p. 54
18. Flegel T, CF Lo (2014) Primers for specific detection of bacterial isolates that cause acute hepatopancreatic necrosis disease (AHPND).

19. Han JE, LL Mohney, KFJ Tang, CR Pantoja, DV Lightner (2015) Plasmid mediated tetracycline resistance of Vibrio parahaemolyticus associated with acute hepatopancreatic necrosis disease (AHPND) in shrimps. Aquaculture Reports 2: 17-21.

20. Joshi J, J Srisala, VH Truong, IT Chen, B Nuangsaeng, et al. (2014) Variation in Vibrio parahaemolyticus isolates from a single Thai shrimp farm experiencing an outbreak of acute hepatopancreatic necrosis disease (AHPND). Aquaculture 428: 297-302.

21. Lightner DV (2014) Documentation of a unique strain of Vibrio parahemolyticus as the agent of Early Mortality Syndrom (EMS) or acute hepatopancreatic necrosis disease (AHPND) affecting Penaeid shrimp with notes on the putative toxins. 9th symposium on Disease in Asian Aquaculture; Ho Chi Minh City, Vietnam. 